Newfoundland and Labrador Studies

\title{
Did Smallwood Neglect the Fisheries?
}

\section{Douglas House}

Volume 33, numéro 2, 2018

URI : https://id.erudit.org/iderudit/1058079ar

DOI : https://doi.org/10.7202/1058079ar

Aller au sommaire du numéro

Éditeur(s)

Faculty of Arts, Memorial University

ISSN

1719-1726 (imprimé)

1715-1430 (numérique)

Découvrir la revue

Citer cette note

House, D. (2018). Did Smallwood Neglect the Fisheries? Newfoundland and

Labrador Studies, 33(2). https://doi.org/10.7202/1058079ar d'utilisation que vous pouvez consulter en ligne.

https://apropos.erudit.org/fr/usagers/politique-dutilisation/ 


\section{Did Smallwood Neglect the Fisheries?}

Douglas House

\section{Introduction}

By the 1970s, it had become customary in academic, media, opposition, and public opinion circles to criticize Newfoundland and Labrador's first premier, Joseph (Joey) Smallwood, for his purported "neglect of the fisheries." I admit to being part of that custom myself, and was one of the contributing authors to a little book put out by the People's Commission on Unemployment called Now That We've Burned Our Boats. ${ }^{1}$ Smallwood claimed that he never said fishermen should burn their boats, nor that he said there would be two jobs for every Newfoundlander; but, as the People's Commission points out in the frontispiece to their book, "they have become part of the province's folk-lore."

In his excellent biography, Smallwood: The Unlikely Revolutionary, Richard Gwyn agrees with the claim that Smallwood neglected the fisheries:

This lack of affection for things maritime is reflected in what is perhaps the largest puzzle of Smallwood's administration: its lack of attention to the fishery. Although the fishery supports one Newfoundlander in three, right down 
to the late 1960's it has been the most neglected industry in the province. For twenty years, Smallwood has sought to turn his people away from the sea. ${ }^{2}$

This has become the conventional wisdom, but the claim that Smallwood neglected the fisheries is a good example of how a statement can become generally agreed upon without having been subjected to critical examination. Based on a review of the historical record and interviews with both Smallwood and Aidan Maloney, who served in several key fisheries positions at the time, this article provides such a critical examination.

\section{The National Convention and Fisheries Jurisdiction, September 1946 to January 1948}

The National Convention, an elected assembly established by the British government to advise on the form of government that would be appropriate for Newfoundland and Labrador after the Second World War, was a very important and underrated body that had major influences on the future of what was to become Canada's tenth province. It instituted a thorough review of the state of affairs in Newfoundland and Labrador at the time, with background reports prepared and debated on such crucial issues as education, the fisheries, and the financial prospects of the country. The Convention favoured several policy directions that were later implemented by the first post-Confederation provincial government. These included elevating Memorial University College into a full-fledged degree-granting university, and promoting the redirection of the Newfoundland and Labrador fisheries more towards fresh frozen production for the American market and away from salted, dried cod for overseas markets. ${ }^{3}$

Joey Smallwood was elected as a member of the National Convention. Although he was not a member of the Fisheries Committee of the Convention, he was assiduous in his review of the Committee's report, in conducting his own investigation of fisheries issues, and in 
contributing to the Convention's debates about the report. In light of his subsequent leadership role in transforming the fisheries, his comments during the debates are insightful.

I have very genuine admiration for the work of the Fisheries Committee in the preparation of this interim report.... I have often wondered whether it was a good thing for Newfoundland to turn away from her centuries-old method of fishing. I do not refer merely to the technical methods of fishing, but to the social or sociological; we have had 30,40 and 50,000 petty capitalists - whether it is a good thing to turn away from that and to industrialize the fishing and increase the units of production; to increase mechanical processing; turn the fishery from what it has so long been, an adventure, a highly individualistic adventure, developing a certain sturdy independence and individualism in our fishermen; turning from that into what can only be called industrialism in the fishery, reaching perhaps ultimately someday to the fishery proletariat - men engaged for wages as they might be in a clothing factory, in a mine or paper mill or any other industrial enterprise. ... My head tells me that we must change; we must become industrialized; we must go ahead or go under; yet I will watch this trend to industrialism in the fisheries with a great deal of interest in the next ten, 20 or 30 years, if I live that long. I know it must come; it is inevitable and indeed it may be regrettable. ${ }^{4}$

Smallwood's ambivalence about the changes he foresaw for the fishing industry and rural Newfoundland and Labrador more generally was to colour his whole career in politics.

Despite making himself quite knowledgeable about fisheries issues, Smallwood, no doubt because he was so passionately committed to the Confederation cause, proved to be somewhat naive about the implications of joining the Canadian federation for control and management 
of the fisheries. During the National Convention debates, he argued that "any regulations they make governing the fisheries ... all the practical details of fishery, that is left entirely completely and absolutely to the province." Fellow Convention member Charles Bailey disagreed, stating "That is not what I was given to understand." In the event, Bailey's understanding was to prove correct. In negotiating the Terms of Union, the Newfoundland delegation could have championed an approach giving a significant say in fisheries administration to the new province of Newfoundland, but this did not happen. Sovereignty and jurisdiction over fisheries resources and their management passed seamlessly to the federal government and its Department of Fisheries.

\section{Fisheries Development during the Smallwood Years, 1949-1972}

The attention given to Smallwood's land-based industrialization schemes, and, indeed, the exaggerated claims about them that he promoted, far exceeded the attention given to fisheries. Aidan Maloney was heavily involved in various fisheries capacities during the Smallwood years, including as a senior manager for John Penny and Sons in Ramea, assistant deputy minister of fisheries in the provincial government, and as minister of fisheries in Smallwood's cabinet. In his opinion, although Smallwood received more publicity for his other industrialization schemes, he was nevertheless also heavily involved in fisheries development:

No one got excited when Fishery Products or Bonavista Cold Storage got a loan of $\$ 2$ million to buy trawlers. That was not the kind of thing that got political attention. If there was a ten-storey building to be built, everybody could see it. If there was a school, a regional high school or something like that, that attracted attention. That had much more political moxie than somebody buying three or four trawlers in Britain or something like that. Joe didn't ignore the fisheries, in fairness to him. But he didn't 
sermonize about it in his talks, they were always on development in other areas. ${ }^{7}$

Earlier, during the debates of the National Convention, Smallwood had expressed his faith in the future of the fisheries as follows:

I have absolute faith in the basic possibilities of the Newfoundland fisheries. We must never forget that over half our entire economy consists of the fisheries and half of the population is directly affected by the fisheries, and that the remainder who are not directly affected, are certainly so in an indirect way. Everyone in Newfoundland stands or falls in the long run by the fisheries. We must not make the mistake of neglecting the fisheries. ${ }^{8}$

He then went on to outline a seven-point plan for what he thought needed to be done to modernize the Newfoundland fishery so that it could be competitive with progressive countries such as Iceland and Norway. This included bringing down the cost of production, scientific research, new methods of production and processing, bringing in outside capital, emphasizing organization by building on the work of the Fisheries Board and the Fish Exports Group, encouraging the co-operative movement, and establishing a separate Department of Fisheries.

After he became premier, Smallwood attempted to follow through on much of this. One of his first actions was to set up a Department of Fisheries and $\mathrm{Co}$-operatives. In keeping with his earlier socialist leanings and his admiration of William Coaker's Fishermen's Protective Union, Smallwood was a keen supporter of the co-operative movement and appointed a well-known co-operative leader, Fred Scott, to be his first deputy minister of co-operatives within the new department. Later, impatient to see economic development happen quickly, Smallwood's interest in the co-op movement seemed to wane.

During Smallwood's 22 years as premier, the fishing industry of Newfoundland and Labrador changed dramatically. Despite his reser- 
vations about what he saw as the inevitable erosion of the outport lifestyle, which was based on a small-boat inshore fishery with familybased production of dried, salted codfish, Smallwood championed the industrialization of the Newfoundland fishing industry. This meant, on the harvesting side, building up the offshore fleet of trawlers and encouraging inshore fishermen to graduate to longliners, which were viewed as being more efficient than the traditional dories and trap skiffs. On the processing side, the government encouraged and helped to capitalize the growth of factory-like fish plants to produce frozen fish. Gradually, over 15 years, industrially produced frozen fish replaced the traditional salt fish as Newfoundland's main seafood export. Both the federal government and the provincial government invested heavily in supporting this transformation.

Despite his criticism of Smallwood's purported lack of attention to the fishery, as quoted above, Richard Gwyn actually appears to contradict himself by going on to describe some of Smallwood's early efforts at fisheries development. In 1950, Smallwood recruited Clive Planta, originally from British Columbia and who was then serving as manager of the Fisheries Council of Canada, to serve as his deputy minister of fisheries. They organized a joint federal-provincial study of the Newfoundland fishery, chaired by Sir Albert Walsh, the chief justice of Newfoundland, who had been a member of the delegation that negotiated the Terms of Union between Canada and Newfoundland. The 1952 Walsh Report recommended a \$100 million fisheries development program to be jointly financed by Newfoundland and Ottawa.

But, as Gwyn points out, "Ottawa, in those days, had scant concern for a decaying fishery on an island two thousand miles away." The federal cabinet summarily dismissed the Walsh Report's recommendations. In 1954, Ottawa also rejected Smallwood and Planta's request to establish a provincial marketing board that would process, package, and market Newfoundland fish. Smallwood's optimistic expectations about federal jurisdiction whereby the province would be in charge of the "practical details," as expressed during the National Convention, were coming back to haunt him. Far from being disinterested 
in the plight of the fisheries, Smallwood was so discouraged by Ottawa's indifference that he even "began to question the benefits of Confederation itself." 10

Smallwood was adamant that he and his government strongly supported development of the fisheries as part of their overall approach to economic development. In an interview I did with him in 1978, six years after he had stepped down as premier, I asked him how he would respond to the criticism that some people were making that he and his government had neglected the fisheries. His response is worth quoting at length, not only because it expresses his own claims about his efforts at fisheries development but also because it offers a good example of Smallwood's colourful style of political rhetoric. I had said: "I suppose some people have criticized the policies of your era, saying that fisheries were neglected too much." He cut in:

... positively, very loudly and very frequently! The answer to it is this: that we have in Newfoundland today something around 30 great fish plants, employing about 10,000 people. Think of that. That's the largest single industry in the province. Do you know how many of the 30 plants there are in Newfoundland that have been opened since I went out of office? Not one. Zero. Zilch. Nara one at all, okay? Not one since I went out. How many were built by me or enabled by me to be built? Out of 30 , there was the one in Harbour Grace, and we lent them several millions, but we didn't put it there. We didn't put the one in Grand Bank - yes we did - we financed that completely. We put the one in Fortune. We did not put the one in Burin, but we put millions of dollars in it to enlarge it. We put all the money in the one in Marystown, all the money in the one in Trepassey - all the plants up and down the Southern Shore - there was perhaps one in Port aux Basques, we put the one in Gaultois, we put the one in Harbour Breton, we put the one in Burgeo, we put the one in Carbonear, we put the one in Bay de Verde, we put the one in 
Old Perlican, we put two in Catalina, we put the one in Twillingate, one in St. Anthony, one in Port aux Choix. We put - my administration - of the 30 fish plants in Newfoundland today, we put all but four of them - that's 26 plants we put in - that's how much we were against the fishery! And we introduced the longliner - and there are 800 of them now - we brought in the longliners and we financed them. We created a fisheries loan board and lent money to thousands of fishermen to buy boats and engines and fishing gear - thousands of fishermen. Again and again, I went on the air and pleaded with people. I said: "We have the money, government has the money, we want to spend it on the development of the fishery. Please come to us, come to us if you want to develop, if you want to start a fish plant, if you want to get a new boat, if you want to get an engine, if you want to get fishing gear." We have a fisheries development board - we have two actually - we have the Fishing Development Authority and the Fisheries Loan Board.

He went on to argue, convincingly in light of the drastic decline in fish stocks in subsequent years, that the fundamental problem was that people within the industry were losing faith due to market difficulties and declining fish stocks.

The fishing industry did not attract people. People were losing faith. I remember when there were 1,000 schooners every year, 1,000 schooners every year going down to the Labrador fishing. I saw it fall from 1,000 a year to $800 \mathrm{a}$ year to 500 a year. I saw it fall to 300 a year, I saw it drop to 200 a year, I saw it drop to 100 vessels a year, I saw it drop to 50 a year, I saw it drop to three vessels - from 1,000 Labrador schooners a year going down to Labrador from Newfoundland, I saw it fall down until there were only three.

[The decline] was irreversible at that time. The price 
of fish was such, the markets were such, the amount of fish attainable was such that people in the fishing industry itself, the fishermen, the skippers, the plant owners - they had lost faith, had lost hope in it. Notwithstanding the tens and tens and tens of millions of dollars which my administration poured in. I started something, and I'm very proud of this. Before they were all built I was out of office. But I started it, the garages, the marine garages, the marine service stations. The first one I think I put over in Harbour Grace, and I put dozens of them around Newfoundland, where you could take your boat in, and a marvellous machine would lift that boat out of the water and bring it into the garages. The servicing of the boats, the larger boats especially — the longliners — the first garages, not for trucks and cars and motor buses and skidoos and such, but for boats, I started them.

Joey the politician no doubt exaggerated his claims about his contributions to fisheries development, and his tendency to attribute all his government's accomplishments, including those supported by generous federal dollars, to himself personally, is irritating and probably worked against him towards the end of his career. But there is no doubt that his government made significant investments in fisheries development. And, in hindsight, his concerns about the decline in fish stocks seem prescient. This also helps explain why Smallwood believed that, in addition to a modernized fishery, he also had to turn to other industries for the economic development he craved.

A premier of a Canadian province, even one as energetic and hard-working as Joey Smallwood, can only achieve so much. To be effective at all, he or she has to focus on some priorities more than others. It was never likely that Smallwood's obsession with making economic development happen quickly would be easily compatible with fisheries development, which, by comparison with his big industrial dreams, was a slow process. In addition, in a sense Smallwood was hoist by his own petard with respect to fisheries, in that Newfoundland 
had surrendered sovereignty over its offshore fisheries resources at Confederation. Smallwood was hopeful that the Canadian government, with its greater resources of capital and technical expertise, would provide the leadership, direction, and investment needed to modernize the Newfoundland fisheries effectively. This happened to some extent - the federal Department of Fisheries (later Fisheries and Oceans) did invest significant funds in research and development. But this never happened in the wholesale, targeted way that Smallwood hoped for.

From the federal government's point of view, despite the addition of Newfoundland and Labrador bringing about a one-third expansion of Canada's fisheries, there appeared to be no need to tailor its approach to the specific needs of the Newfoundland fisheries; rather, the great fisheries resources offshore Newfoundland and Labrador were incorporated into the even greater fisheries resources of Canada as a whole. These were now Canadian resources under federal government jurisdiction and, except for a five-year transition process, they were to be treated in the same way as fisheries had been treated by the federal Department of Fisheries before 1949. This can clearly be seen through reviewing the federal department's annual reports for the years leading up to and immediately following Confederation. The 1948-49 report makes no mention at all of Newfoundland. ${ }^{11}$ The 1949-50 report states, without commentary, that of the two billion pounds of fish caught in Canada for that year, approximately one-third came from Newfoundland, one-third from the Maritime provinces and Quebec, and one-third from British Columbia and the inland provinces. Expenditures by province were as follows: Newfoundland, $\$ 940,181$; Nova Scotia, $\$ 1,287,563$; New Brunswick, $\$ 1,044,490$; British Columbia, $\$ 1,981,448 .{ }^{12}$ The great fisheries of Newfoundland and Labrador were simply incorporated into the workings of the federal Department of Fisheries as another region to be managed and administered in the same way as the already established regions. No strategy or plan was tailor-made to this region. Indeed, it became common, as in the 1950-51 annual report, to refer to "the problems of the Atlantic coast fishermen" and "the problems" of Newfoundland in particular. ${ }^{13}$ 
A decade later, clearly disappointed at how fisheries development was progressing in the new province, Smallwood took to the air. In an impassioned province-wide radio and television address, printed verbatim in the Evening Telegram in 1962, ${ }^{14}$ Smallwood reiterated his faith in and concern about the fisheries, pointing out that 32 of the 41 electoral districts in the province at that time were largely dependent on the fisheries. In his words:
It is only a mockery to say that Newfoundland is going ahead if our fisheries do not go ahead. It is essential that the fishing industry shall flourish and expand. What we need to bring this about is a new policy; a new program; a new scheme; we need to get our fishery onto a new foundation.

He went on to admit, however, that although "I feel that something special, something big, must be done for our fisheries, I don't know what it is." But he disclaimed that it was neither the provincial nor the federal government's responsibility to set this "new foundation," although it would be their responsibility to support it once it was established. Instead, and somewhat surprisingly given his earlier disdain for "the merchants of Water Street," he argued that "it is the duty of the merchants to create the actual program or plan," although he later amended this to read the merchants' and the fishermen's duty.

To this end, Smallwood called for a great convention of merchants and fishermen to devise such a plan, with federal and provincial officials to play a supportive role. Such a convention was held but the merchants and fishermen that Smallwood challenged were unable to produce the fisheries development plan that he hoped for. Smallwood and his government nevertheless continued to work towards such a plan. Given that the Terms of Union had conceded jurisdiction over fisheries to Ottawa, Smallwood attempted to convince the federal government to embark on a national approach to fisheries development, modelled on its national agriculture policy. He pursued this personally during a federal-provincial conference on fisheries development in 1964. 
The federal government's position on fisheries jurisdiction was and remains unequivocal. As stated in a background paper prepared for the conference, based on the British North America Act of 1867, "the parliament of Canada has exclusive legislation authority over fisheries as such, both coastal and inland"; and, even in tidal waters, "the provincial legislature is entirely without jurisdiction." 15

For Smallwood, the 1964 conference was meant to be pivotal in his attempts at fisheries development. He was the only provincial premier who personally led his province's delegation to the conference. Implicitly conceding that federal jurisdiction was non-negotiable, he hoped to convince the federal government to develop and implement a national fisheries policy modelled on agriculture policy. In his address to the conference, Smallwood advocated as follows:

Based upon the programmes and accomplishments in agriculture, it is possible to define in relatively precise terms the objectives of a National Fisheries Policy. The following should be the agreed objectives:

1. To create an environment of price stability essential for development, employing whatever means are necessary, including marketing boards.

2. To increase productivity.

3. To expand markets.

4. To initiate community development.

5. To improve and standardize product quality.

He went on to argue that "if policy is designed to achieve these objectives there is no reason why the progress that has typified agriculture could not also become typical of fisheries." ${ }^{16}$

Despite the Newfoundland premier's direct advocacy to the conference, the proposal for a national fisheries policy was rejected. This was a great disappointment to Smallwood and the Newfoundland delegation. Unlike agriculture, fisheries had no great national appeal. ${ }^{17}$ Nevertheless, as Aidan Maloney, the assistant deputy minister of fisheries at the 
time and a member of the Newfoundland delegation, points out, some of the measures proposed by the province were eventually acted on in a piecemeal way rather than as part of an integrated policy. These included the community stage program and a bait-for-fishermen program, both of which were very helpful for Newfoundland fish harvesters and fishing communities.

Another important initiative was the establishment of a national body to coordinate the marketing of salt fish, the Canadian Salt Fish Corporation. Maloney himself, by then a member of Smallwood's cabinet, was to resign from the provincial government in 1969 to head up the Corporation. The Corporation was successful during its first years, but soon found itself troubled by the decreasing size of Newfoundland codfish. The best markets for salt fish were in Italy, Portugal, Spain, and Brazil. Although Newfoundland had been well established in those markets, as the average size of fish from Newfoundland decreased, buyers, who were looking for fairly thick pieces of fish, began to switch to other producers in Norway and Iceland. In Maloney's words: "Oh, it was terrible. I saw what the Norwegians and the Icelanders were putting into Brazil and there was no way in God's name that we could compete." Small salt fish from Newfoundland and Labrador could then only be sold in poorer markets in Puerto Rico, Jamaica, and Barbados. This was not profitable and the decline in the historic salt fish trade hastened the transformation to the production of frozen cod for the US market. ${ }^{18}$ The Canadian Salt Fish Corporation was eventually shut down in 1994.

The decline in the size of codfish from the waters off Newfoundland and Labrador in the 1970s was a dire harbinger of the subsequent decline of stocks during the 1980s leading up to the devastating cod moratorium of 1992. In 1973, Maloney had written to Jack Davis, then the federal minister of fisheries, warning about the decline in the size of fish and the loss of the big mother fish that were crucial for reproduction. But, in Maloney's words, "I was a voice in the wilderness.... The politics of the resource had no time for that sort of thing." During the Smallwood years, the conservation of fish stocks was 
not seen as an issue. From 1948 to 1961 world fish landings doubled. Rather than worry about the future of the resource, Canada was committed to becoming more competitive with foreign fishing nations, which at the time were taking about two-thirds of Atlantic groundfish landings. The issue was: how can we build up our own national harvesting capacity to compete with the larger vessels and advanced technology of the foreign fleets? From this perspective, the inshore fisheries of Newfoundland and Labrador were perceived as being out-of-date, old-fashioned, and unproductive.

Smallwood himself never took a clear stand on this matter. On the one hand, he bought into the argument that the fisheries had to be modernized and industrialized to become competitive and thereby successful. On the other hand, he admired the culture and way of life of outport Newfoundland, and, more to the point, was dependent on the outports for their continued political support. Not surprisingly, in that context the Smallwood government (and subsequent provincial governments) continued to support the inshore fisheries through bounties and subsidies to both fish harvesters and inshore processing plants. ${ }^{19}$

Smallwood was also concerned about the welfare of fishermen and their families, whose incomes from fishing were low by national standards. While seasonal fish plant workers were able to supplement their income through regular unemployment insurance (UI), this was not initially the case for fishers, who were seen as self-employed and therefore ineligible for UI. Smallwood and Jack Pickersgill, Newfoundland's influential representative in the federal cabinet, were keen to change that situation. Pickersgill, who had been a successful senior public servant in Ottawa before turning to politics, knew how to work the Ottawa system. Pickersgill had to convince his cabinet colleagues to overcome "the stubborn resistance of the bureaucracy." He dealt with the matter of fishermen being seen as self-employed by proposing that the law be changed such that the merchants who bought the fish would be deemed employers for insurance purposes. Eventually, convincing Prime Minister Louis St. Laurent that he could not face his constituents in Bonavista-Twillingate unless fishermen were covered, he got his 
way in cabinet. The Unemployment Insurance Act was amended and fishermen became eligible for UI as of 1 April 1957. Proud of his success, Pickersgill states in his autobiography: "I regarded my part in securing the extension of unemployment insurance to fishermen as my most substantial contribution to my constituents and of Newfoundland in general." ${ }^{20}$

Unemployment insurance for both fish harvesters and fish plant workers had a profound influence in maintaining the rural lifestyles of people in Newfoundland and Labrador outports for many years. Although not specifically designed as such, the UI program for fish harvesters really functioned as a form of income supplementation for low-earning primary producers in a seasonal industry. While a strong case can be made for such an income supplementation scheme (preferably, one designed for the purpose) on equity and community development grounds, it was criticized by both mainstream economists and many government officials for its economic impacts. One economist, William Schrank of Memorial University, later even went so far as to contend that fishermen's UI "became the single greatest hindrance to the long term adjustment of the Canadian Atlantic fishery into a commercially viable industry." ${ }^{21}$

Schrank's contention is consistent with the dominant academic paradigm that characterized economists' views of fisheries development throughout the second half of the twentieth century, both globally and within Canada. Harking back to Scott Gordon's influential argument about "the tragedy of the commons" and Parzival Copes's contention that there were too many fishing communities and too many fishermen in coastal Newfoundland and Labrador, this dominant economic view shaped the thinking of most federal government officials and several provincial officials as well..$^{22}$ According to this economic paradigm and its market-driven logic, communities, families, and individuals should "adjust" to the tough economic realities by finding alternative employment, moving to larger centres in Newfoundland, or migrating to mainland Canada in search of work. The disruption to these people's lives - giving up their homes, trying to 
retrain for unfamiliar jobs, seeing their children move away, was simply part of the cost of progress.

The most cogent critique of this paradigm during the post-war years was articulated by the Hungarian-American political economist, Karl Polanyi, who argued that this market-driven mentality has its own contradictions in the disruption it can inflict on people and the environment. ${ }^{23}$ In the case of fisheries, the world has paid the price in the over-exploitation of fish stocks and degradation of the marine environment due to the rapacious activities of highly mechanized (productive, efficient) industrial fishing fleets. In Canada, Newfoundland and Labrador would suffer severely from this during the 1990s and beyond.

Joey Smallwood, and many other politicians at the time and subsequently, felt instinctively uncomfortable about the dire consequences for communities and people that would be entailed by a too rigid adherence to the economic, market-driven paradigm. ${ }^{24}$ They lacked an articulate alternative paradigm, but, pragmatically, they recognized the value in human terms of thriving small communities, outport culture, and sustainable marine ecosystems. For social and cultural as well as political reasons, they engaged in the subsidization of inshore fish harvesters and fish plants, and income supplementation through unemployment insurance and, where needed, social assistance. If this was upsetting to academic economists and Ottawa bureaucrats, then so be it.

\section{Fisheries, Industrialization, and Modernization}

Premier Joseph Smallwood did not neglect the fisheries. Rather, the industrialization and modernization of the fisheries were as much a part of his overall approach to economic development as were his higherprofile efforts at diversification through small-scale manufacturing and large-scale resource projects. Smallwood actively supported the industrialization of the fisheries during the 1950s through loans and subsidies to the province's largest fishing companies so they could invest in offshore trawlers and modern fish plants to produce frozen products. ${ }^{25}$

Smallwood's ambivalence about tradition and modernity, and his 
political pragmatism, also informed his controversial community centralization program, better known as the resettlement program. $\mathrm{He}$ had a mandate to modernize rural Newfoundland and Labrador - to provide electricity, roads, schools, and access to health care to the people of the new province, to ensure that they enjoyed the same services and benefits as Canadians in other provinces. The cost of this modernization, however, was very high. The cost of providing modern services to every small community in every small offshore island and remote coastal location would have been prohibitive. Pragmatically, it made sense that, if people in such communities agreed to move to more central locations, then they could enjoy the benefits of modern services and amenities.

Resettlement occurred in two phases. The first, a provincial-only program that offered limited financial support from 1954 to 1965, saw 115 communities and about 8,000 people resettled. The second, a joint federal-provincial program that provided more generous support from 1965 to 1970 , saw a further 119 communities and 16,114 people resettled. In addition to making modern amenities and services more readily available, the latter program also aimed to require people to move into designated "growth centres," with the hope that, in keeping with economic agglomeration theory, the larger centres would allow for more industrial growth and business and employment spinoffs. ${ }^{26}$ The main industry that would encourage this sort of development was the frozen fish industry. During the 1970s and 1980s many towns in Newfoundland, for example La Scie, Arnold's Cove, Trepassey, and Catalina, did enjoy growth through the establishment and expansion of modern fish plants that provided income and employment to many rural men and women in these towns and their surrounding areas. These plants, however, were not clearly tied into the formal federalprovincial resettlement program. Many of those who moved settled in smaller communities where new economic opportunities were scarce. A lot of fishers were dislocated from their traditional fishing grounds, and there is little evidence to support the claim that the growth-pole approach worked for this program. 
Government-sponsored resettlement (as compared to voluntary resettlement, of which there was a lot as well) also caused serious social disruptions and psychological hardships for many people. As described in an article at the Newfoundland and Labrador Heritage website:

\begin{abstract}
There were significant problems. Three groups had the most difficulty: the elderly, widows, and large family households. The biggest issue was the availability of affordable housing. For many it was a double loss. Houses in the communities left behind were worthless, and even with relocation assistance, few could afford to buy or build new homes elsewhere. The elderly, with little chance of earning a living, could not afford to start again. Widows were in much the same position, especially those with young children. Families with large numbers of children could not afford to build houses suitable to their needs, and there were few homes available that could accommodate large families. ${ }^{27}$
\end{abstract}

Resettlement also caused a lot of anxiety for people who lived in small communities and feared that they were on "the government list" slated for resettlement. In some regions, notably Fogo Island, local communities organized to oppose resettlement and lobbied instead for local community development. Politically, controversy about resettlement became the first chink in the armour to Smallwood's hold on rural Newfoundland and provided an opportunity for a revitalized Progressive Conservative Party to appeal to rural voters in the 1970s.

After his disappointing attempt to persuade the federal government to pursue a great national fisheries policy, modelled on its national agriculture policy, it wasn't so much that Smallwood neglected or gave up on the fisheries, but that (like most premiers who succeeded him) he was unsure of how best to proceed. Turning his own economic development energies to large-scale industrial resource projects, he left fisheries matters more in the hands of his provincial minister of fisheries and the federal Department of Fisheries and Oceans. 


\section{Conclusion}

What can we conclude about the claim that "Smallwood neglected the fisheries"? Edward Roberts, who worked with Smallwood for many years, first as executive assistant and later as a cabinet minister, ${ }^{28}$ supports the contention that "Smallwood never said 'burn your boats.' Everybody says he said it, but nobody has ever said here's the speech, or here's the letter, or here's the document. In any event, Smallwood spent millions on the fishery." ${ }^{29}$ In her historical overview of federal and provincial involvement in the industrialization of the Newfoundland fishery from 1934 to 1968, Miriam Wright agrees about Smallwood that "the man who wrapped himself in the banner of Confederation, led Newfoundland into Canada, and then reigned for over two decades made a profound impact on the fishery." ${ }^{30}$

One could argue that, during the debates of the National Convention and during the negotiations of the Terms of Union, Smallwood (as well as other delegates) did indeed neglect the fisheries by too easily surrendering control over one of the world's great fisheries resources to the Canadian government, for whom fisheries were and continue to be of minor importance in the overall scheme of national affairs, dominated by the concerns of Ontario, Quebec, and the western provinces. Time would prove that Smallwood had been unduly optimistic about the purported advantages of surrendering sovereignty over fisheries and other offshore resources to the federal government. He failed to appreciate that the mindset of federal fisheries officials, conditioned by the conventional economic thinking of the time, would have negative consequences not only for most of Newfoundland and Labrador's fishing communities, but also for the abundant stocks of cod and other fish species offshore the island and the coast of Labrador. Once jurisdiction is surrendered it is extremely difficult if not impossible to get it back, as subsequent premiers were to learn. Brian Peckford in particular was to fight passionately but unsuccessfully for joint management of fisheries, based on the model of the Atlantic Accord for joint federalprovincial management of offshore oil and gas. 
Given that after Confederation in 1949 Newfoundland and Labrador no longer had jurisdiction over its fisheries resources, a dispassionate review of the provincial government's fisheries policies and programs during Joey Smallwood's long tenure as premier shows that fisheries issues were important to his government's efforts at economic development. Smallwood was indeed passionately committed to economic development through small-scale manufacturing and largescale resource projects. These highly publicized efforts tended to overshadow his government's support for the fisheries. The Smallwood government's attempts at fisheries development should be viewed as part of its overall approach to development, not neglected but rather one important component of his ambitious program to, in his famous phrase, "develop or perish."

\section{Notes}

1 The People's Commission on Unemployment, "Now that we've burned our boats...": The Report of the People's Commission on Unemployment, Nervfoundland and Labrador (Ottawa: Mutual Press, 1978).

2 Richard Gwyn, Smallwood: The Unlikely Revolutionary (Toronto: McClelland and Stewart, 1968), 171.

3 As Miriam Wright points out, this movement from salt fish to frozen fish was already being encouraged by the Commission of Government during the 1940s. In her words: "Fisheries planners believed that frozen fish plants paying cash for fish, and providing wages for others, could be the seeds that fostered the growth of a diversified, cash-based economy in rural Newfoundland." Miriam Wright, "The Background to Change in the Newfoundland Cod Fishery at the Time of Confederation," Nerwfoundland Studies 14, no. 2 (Fall 1998): 258.

4 J.K. Hiller and M.F. Harrington, The Newfoundland National Convention, 1946-1948, Volume One: Debates (Montreal and Kingston:

McGill-Queen's University Press, 1995), 82.

5 Ibid., 845.

6 Ibid., 846. 
7 This and subsequent quotes from Aidan Maloney are based on an interview I conducted with him in 2010. Aidan Maloney died in March 2018.

8 Hiller and Harrington, The Nerufoundland National Convention, Volume One, 423.

9 Gwyn, Smallwood: The Unlikely Revolutionary, 172.

10 Ibid., 173.

11 Department of Fisheries, Nineteenth Annual Report, 1948-49.

12 Department of Fisheries, Twentieth Annual Report, 1949-50.

13 Department of Fisheries, Twenty-First Annual Report, 1950-51, 8, 54.

14 "Premier calls fish meetings," Evening Telegram, 14 Sept. 1962.

15 Department of Fisheries, Federal-Provincial Fisheries Conference on Fisheries Development (Ottawa, 1964), 27.

16 Government of Newfoundland, "National Fisheries Development: The Presentation to the Federal-Provincial Conference on Fisheries Development," 20 Jan. 1964, 18.

17 As Raymond Blake points out in his book about Newfoundland and Labrador becoming the tenth province of the Canadian Confederation, the federal government was also wary about providing special support to Newfoundland fisheries development beyond what would be provided to other provinces, especially Nova Scotia. In Blake's words, "the federal government refused to venture outside normal government services to rehabilitate the industry." Raymond B. Blake, Canadians at Last: Canada Integrates Nerfoundland as a Province (Toronto: University of Toronto Press, 1994), 175.

18 For a critical account of the decline of the salt fish industry in Newfoundland and Labrador, see David Alexander, The Decay of Trade: The Economic History of the Newfoundland Salt Fish Trade, 1935-1965 (St. John's: ISER Books, 1977).

19 Later, after the Smallwood era, some federal ministers and officials, influenced in part by the new Newfoundland Fish, Food and Allied Workers Union, were to become more supportive of the inshore fisheries, notably through the Fleet Separation and Owner Operator policies, which inhibited takeovers by large corporations.

20 J.W. Pickersgill, Seeing Canada Whole: A Memoir (Markham, ON: Fitzhenry \& Whiteside, 1994), 420. 
21 William E. Schrank, "Benefiting Fishermen: Origins of Fishermen's Unemployment Insurance, 1935-1957," Journal of Canadian Studies 33, no. 1: (1998): 80.

22 H. Scott Gordon, "The Economic Theory of a Common Property Resource: The Fishery," Journal of Political Economy 62 (1954): 124-42; P. Copes, The Resettlement of Fishing Communities in Nerwfoundland (Ottawa: Council on Rural Development, 1972).

23 Karl Polanyi, The Great Transformation: The Political and Economic Origins of Our Time (Boston: Beacon Hill, 1957).

24 More recently, an alternative paradigm, based on empirical research of fishing communities and fishing people, has emerged that emphasizes a community-based, ecologically sustainable approach to fisheries management and development. See, for example, Douglas House, Maura Hanrahan, and David Simms, Fisheries Policies and Community Development: Proposal for a Revised Approach to Managing the Inshore Fisheries in Nerwfoundland, Background Report to the Royal Commission on Employment and Unemployment, Newfoundland and Labrador, 1986; Peter R. Sinclair, ed., A Question of Survival: The Fisheries and Nerwfoundland Society (St. John's: ISER Books, 1988); David Ralph Matthews, Controlling Common Property: Regulating Canada's East Coast Fishery (Toronto: University of Toronto Press, 1993); Rosemary E. Ommer, Coasts Under Stress: Policy Reflections (St. John's: ISER Books, 2006); Barbara Neis with Rosemary Ommer and Pam Hall, Moving Forward: Building Economically, Socially and Ecologically Resilient Fisheries and Coastal Communities, a Policy Booklet (St. John's: Community-University Research for Recovery Alliance, 2014); Paul Foley and Charles Mather, "Making Space for Community Use Rights: Insights From 'Community Economies' in Newfoundland and Labrador," Society \& Natural Resources 29, no. 8: (2016): 965-80.

25 Miriam Wright, A Fishery for Modern Times: The State and the Industrialization of the Nerwfoundland Fishery, 1934-1968 (Toronto: Oxford University Press, 2001), 81.

26 See, for example, Mette Monsted, "François Perroux's Theory of 'Growth Pole' and 'Development' Pole: A Critique,' Antipode 6, no. 2 (July 1974): 106-13. 
27 Melanie Martin, “The Resettlement Program,”Newfoundland and Labrador Heritage website, 2006, 4.

28 Roberts subsequently succeeded Smallwood as leader of the Liberal Party in opposition, and later served as a minister in the governments of both Clyde Wells and Brian Tobin, as chair of the Board of Regents of Memorial University, and as lieutenant-governor of Newfoundland and Labrador.

29 Quoted from an interview by the author with Edward Roberts in 2011.

30 Wright, $A$ Fishery for Modern Times, 48. 